\title{
ANALISIS PREDIKSI KEBANGKRUTAN MENGGUNAKAN METODE ALTMAN (Z-SCORE) PADA PERUSAHAAN FARMASI (STUDI KASUS PADA PERUSAHAAN YANG TERDAFTAR DI BURSA EFEK INDONESIA TAHUN 2011-2015)
}

\author{
Fitria Wulandari, Burhanudin, dan Rochmi Widayanti \\ Fakultas Ekonomi Universitas Islam Batik Surakarta \\ Jl. KH. Agus Salim No. 10 Surakarta 57147 Telp. (0271) 714751 \\ fitria07.fw@gmail.com,rochmiwidayanti@gmail.com
}

\begin{abstract}
Abstraksi: Penelitian ini bertujuan untuk menganalisis kondisi perusahaan menggunakan metode Altman Z-Score dalam memprediksi potensi kebangkrutan pada 5 perusahaan farmasi yang terdaftar di Bursa Efek Indonesia tahun 2011 - 2015. Pengambilan sampel menggunakan teknik purposive sampling dengan sampel 5 perusahaan farmasi. Jenis penelitian deskriptif dengan pendekatan kuantitatif. Hasil penelitian menunjukkan bahwa : (1) pada tahun 2011 - 2015 pada kelima perusahaan farmasi berada dalam kategori sehat, nilai Z-Score seluruh perusahaan $\geq$ 2,99. (2) selanjutnya dari kelima perusahaan farmasi yang dianalisis PT Merck Tbk pada tahun 2011, 2013 dan 2014 memiliki nilai Z-Score paling tinggi yaitu sebesar 8,45, 6,3 dan 5,93. (3) PT Kalbe Farma Tbk pada tahun 2012 dan tahun 2015 memiliki nilai Z-Score paling tinggi yaitu sebesar 6,08 dan 5,92. Hasil dari penelitian ini diharapkan perusahaan farmasi dapat menjaga likuiditasnya dalam memenuhi semua kewajibannya sehingga menarik minat para investor dan kreditor. Perusahaan diharapkan dapat mengelola aktiva untuk meningkatkan penjualan dan menghasilkan laba.
\end{abstract}

Kata Kunci: Perusahaan Farmasi, Kebangkrutan, Altman Z-Score

\begin{abstract}
This study aimed to analyze the condition of the company using the Altman Z-Score to predict the potential bankruptcy of the five pharmaceutical companies listed on the Indonesia Stock Exchange in 2011 to 2015. The sampling method is using purposive sampling with a sample of five pharmaceutical companies. This research is descriptive with quantitative approach. The results showed that: (1) in 2011 to 2015 the five pharmaceutical companies are in the good category, the number of Z-Score from all companies are $\geq 2.99$. (2) Moreover from the five pharmaceutical companies that were analyzed PT Merck Tbk in 2011, 2013 and 2014 had the highest number for Z-Score at 8.45, 6.3 and 5.92. (3) PT Kalbe Farma Tbk in 2012 and 2014 had the highest number for Z Score at 6.08 and 5.91. The results of this study are expected for pharmaceutical companies to maintain liquidity to meet all its obligations so that will interest investors and creditors. Companies are expected to manage assets to increase sales and generate profits.
\end{abstract}

Keywords: Pharmaceutical Companies, Bankruptcy, Altman Z-Score

\section{PENDAHULUAN}

Setiap perusahaan didirikan dengan harapan akan menghasilkan profit sehingga mampu untuk bertahan dan berkembang dalam jangka waktu yang sangat panjang. Hal ini berarti dapat diasumsikan bahwa perusahaan akan terus bertahan dan diharapkan tidak mengalami likuidasi (Octarie, 2015). Persaingan bisnis yang semakin tinggi, cepat dan kompetitif diantara berbagai perusahaan baik pada tingkat domestik dan internasional disebabkan oleh globalisasi dan kemajuan teknologi. Oleh karena itu, para manajer dituntut memiliki kemampuan pengelolaan perusahaan yang lebih baik agar 
perusahaan bisa bergerak cepat dalam rangka mengantisipasi perubahan yang ada.

Kinerja industri farmasi di Indonesia telah mencatat pertumbuhan signifikan. Dari sisi total nilai pasar farmasi domestik tercatat lebih tinggi dibandingkan Malaysia dan Singapura. Padahal dari sudut belanja kesehatan, Indonesia masih tergolong rendah. Performa sektor farmasi tidak terlepas dari pertumbuhan makro dan ekspansi usaha yang dilakukan para emiten. (Kemenperin, 2016)

Industri farmasi menarget pertumbuhan 11\% sepanjang tahun 2016. Target tersebut diharapkan tercapai, seiring pertumbuhan ekonomi yang diprediksi makin membaik. Ketua Umum GP Farmasi Indonesia Johannes Setijono menyebutkan, dalam lima tahun terakhir rata-rata pertumbuhan industri farmasi mencapai $11 \%$. Pada tahun lalu pasar farmasi di Indonesia mencapai Rp 62 triliun. Kinerja industri farmasi terkait dengan pertumbuhan ekonomi sehingga akan berdampak pada sektor kesehatan, seperti tumbuhnya apotek, rumah sakit, dan program JKN. Pada kuartal 1/2016 diperkirakan industri farmasi akan tumbuh 9\% Apabila pertumbuhan ekonomi bisa naik 5,1\%, program JKN akan meningkatkan pertumbuhan industri farmasi dari sisi volume tetapi tidak dengan nilai rupiah dalam perusahaan.

Saat ini beberapa perusahaan farmasi sedang melakukan join venture dengan perusahaan asing dalam membangun pabrik bahan baku. Dibutuhkan waktu sekitar 3-4 tahun dalam membangun pabrik tersebut. Direktur Jenderal Bina Kefarmasian dan Alat Kesehatan Kementerian Kesehatan Maura Linda Sitanggang mengemukakan, pasar farmasi Indonesia memiliki potensi untuk dikembangkan lebih baik. Sebagian kecil industri farmasi sudah berbasis research, misalnya menghasilkan vaksin biological. Melalui industri farmasi berbasis research, secara tidak langsung industri sudah bisa melakukan inovasi. Dengan berbasis research, maka harus berbahan baku serta menghasilkan jenis produk sendiri. (Oktiani, 2016)
Kepailitan suatu perusahaan biasanya diawali dengan kesulitan keuangan (financial distress) yang ditandai oleh adanya ketidakpastian profitabilitas pada masa yang akan datang. Prediksi tentang kondisi keuangan perusahaan, yang berkaitan dengan kepailitan, memberikan panduan bagi pihak yang berkepentingan tentang kinerja keuangan perusahaan apakah akan mengalami kesulitan atau tidak dimasa yang akan datang. Sedangkan bagi pihak yang berada diluar perusahaan khususnya para investor untuk menilai kondisi keuangan dan hasil operasi perusahaan saat ini dan dimasa lalu serta sebagai pedoman mengenai kinerja perusahaan dimana perusahaan tersebut apakah akan berpotensi untuk bangkrut atau tidak. (Butet, 2012)

Berbagai macam metode analisis kebangkrutan dari sektor keuangan telah dikembangkan dan digunakan oleh berbagai negara, salah satunya adalah Altman dengan metode Z-Score. Analisis Z-Score pertama kali dikemukakan oleh Edward I Altman pada tahun 1968 atas penelitian yang dilakukan di Amerika Serikat khusus perusahaan manufaktur yang go public. Tahun 1984 model kebangkrutan tersebut direvisi agar dapat digunakan untuk private manufacturing company dan go public. Selanjutnya pada tahun 1995 Altman memodifikasi kembali modelnya agar dapat diterapkan pada semua jenis perusahaan. Peneliti memilih untuk menggunakan metode analisis Altman (metode Z-Score), karena metode Z-Score mudah digunakan serta mampu memperoleh tingkat ketepatan prediksi hingga 95\%. (Rafles, 2015)

\section{RUMUSAN MASALAH}

Pasar farmasi Indonesia merupakan yang terbesar di ASEAN. Demikian pula halnya dengan proyek bantuan kesehatan dari lembaga internasional juga telah memberikan kontribusi pada perkembangan industri farmasi secara keseluruhan. Program JKN 
dari regulasi pemerintah meningkatkan pertumbuhan industri farmasi dari sisi volume tetapi tidak dengan nilai rupiah dalam perusahaan. Ketidakmampuan perusahaan mengantisipasi perkembangan global akan mengakibatkan penurunan dalam volume usaha yang pada akhirnya perusahaan akan mengalami kebangkrutan. Beberapa rumusan masalah dalam penelitian ini adalah :

Berapa nilai rasio Altman Z-Score pada perusahaan farmasi yang terdaftar di Bursa Efek Indonesia pada tahun 2011 - 2015?

Bagaimana prediksi potensi kebangkrutan dengan menggunakan metode Altman Z-Score pada perusahaan farmasi yang terdaftar di Bursa Efek Indonesia pada tahun 2011 $2015 ?$.

\section{LANDASAN TEORITIS}

\section{Laporan keuangan}

Laporan keuangan adalah laporan yang menunjukkan kondisi keuangan perusahaan pada saat ini atau dalam suatu periode tertentu. (Kasmir, 2015: 7)

Analisa laporan keuangan perlu dilakukan secara cermat dengan menggunakan metode dan teknik analisis yang tepat sehingga hasil yang diharapkan benar-benar tepat pula. Kesalahan dalam memasukkan angka atau rumus akan berakibat pada tidak akuratnya hasil yang hendak dicapai. Kemudian, hasil perhitungan tersebut, dianalisis dan diinterpretasikan sehingga diketahui posisi keuangan yang sesungguhnya. Kesemuanya ini harus dilakukan secara teliti, mendalam, dan jujur. (Kasmir, 2015: 67)

\section{Kebangkrutan}

Menurut Hanafi (2014: 638) menyatakan perusahaan dapat dikatakan bangkrut apabila perusahaan itu mengalami kesulitan yang ringan (seperti masalah likuiditas), dan sampai kesulitan yang lebih serius, yaitu solvabel (utang lebih besar dibandingkan dengan asset).

\section{Faktor-faktor Penyebab Kebangkrutan}

Penelitian yang dilakukan oleh Mar'ati, Suhadak dan Rustam pada tahun 2014 menyebutkan faktor-faktor yang menyebabkan terjadinya kebangkrutan pada perusahaan adalah:

\section{Faktor Umum}

(a) Faktor ekonomi, dari gejala inflasi dan deflasi dalam harga barang dan jasa, kebijakan keuangan serta suku bunga. (b) Faktor sosial, adanya perubahan gaya hidup masyarakat serta kerusuhan atau kekacauan yang terjadi di masyarakat. (c) Faktor teknologi, dimana adanya pembengkakan biaya yang ditanggung oleh perusahaan karena sistem tidak terpadu dan pengguna yang kurang profesional. (d) Faktor pemerintah, dimana kebijakan pemerintah terhadap pencabutan subsidi pada perusahaan industri dan kebijakan undang-undang baru.

2. Faktor Eksternal

(a) Faktor pelanggan, dimana untuk menghindari kehilangan konsumen perusahaan harus melakukan identifikasi sifat konsumen juga menciptakan peluang mendapatkan konsumen baru. (b) Faktor pemasok/kreditor, dimana kekuatannya terletak pada pemberian pinjaman yang tergantung pada kepercayaan kreditor terhadap kelikuiditan suatu perusahaan. (c) Faktor pesaing, dimana menyangkut perbedaan pemberian pelayanan kepada konsumen.

3. Faktor Internal yang meliputi dari terlalu besarnya kredit yang diberikan kepada nasabah, manajemen yang tidak efisien, penyalahgunaan wewenang dan kecurangan.

\section{Alternatif Perbaikan Kesulitan Keuangan}

Beberapa alternatif perbaikan kesulitan keuangan berdasarkan besar kecilnya permasalahan keuangan yang dihadapi oleh perusahaan (Hanafi, 2014: 641) : 
1. Permasalahan secara informal dilakukan apabila masalah masih belum parah. Cara pemecahannya adalah sebagai berikut : (a) Perpanjangan (Extension) dilakukan dengan memperpanjang jatuh tempo hutanghutang. (b) Komposisi (Composition) dilakukan dengan mengurangi besarnya tagihan. (c) Likuidasi dilakukan apabila nilai likuidasi lebih besar dibandingkan nilai going concern.

2. Pemecahan secara formal dilakukan apabila masalah sudah parah. Pemecahan secara formal melibatkan pihak ketiga yaitu pengadilan. Cara pemecahannya adalah sebagai berikut : (a) Apabila nilai perusahaan diteruskan $>$ nilai perusahaan dilikuidasi, maka perusahaan mengambil langkah reorganisasi, yaitu merubah struktur modal menjadi layak. (b) Apabila nilai perusahaan diteruskan $<$ nilai peusahaan dilikuidasi, maka perusahaan lebih baik mengambil langkah likuidasi dengan menjual asset-asset perusahaan kemudian didistribusikan ke pemasok modal di bawah pengawasan pihak ketiga.

\section{Metode Analisis Altman Z-Score}

Analisis Z-Score Altman merupakan salah satu teknik statistik analisis diskriminan yang dapat digunakan untuk memprediksi kebangkrutan perusahaan. Metode Altman dikembangkan oleh seorang peneliti kebangsaan Amerika Serikat yang bernama Edward I. Altman pada 1969, dengan menggunakan rasio - rasio keuangan. Berikut adalah rumus dari model Altman (Z-Score) :

$$
\begin{gathered}
Z=1,2 X_{1}+1,4 X_{2}+3,3 X_{3}+0,6 X_{4}+1,0 X_{5} \\
\text { Sumber: (Hanafi, 2014: 656) }
\end{gathered}
$$

Keterangan :

$\mathrm{Z}=$ Indeks Kebangkrutan

$\mathrm{X} 1=$ Modal Kerja (Aktiva lancar - Hutang Lancar) / Total Aktiva

$\mathrm{X} 2=$ Laba Ditahan $/$ Total Aktiva

X3 = Laba Sebelum Bunga dan Pajak / Total Aktiva

X4 = Nilai Pasar Saham Biasa dan Saham Preferen / Nilai Buku Total Hutang
X5 $=$ Penjualan $/$ Total Aktiva

Perusahaan-perusahaan yang diteliti kemudian digolongkan menjadi 3 golongan yaitu perusahaan yang tidak bangkrut, perusahaan yang termasuk rawan dan perusahaan yang berpotensi bangkrut (Hanafi, 2014: 657). Penggolongan ini berdasarkan nilai $\mathrm{Z}$ yang merupakan indeks keseluruhan dari fungsi multiple discriminant analysis dengan kriteria penilaian sebagai berikut:

1. Z-Score $>2,99$ dikategorikan sebagai perusahaan yang sangat sehat sehingga dapat dikategorikan dalam perusahaan tidak bangkrut (Hanafi, 2014: 657).

2. 1,81<Z-Score $<2,99$ berada di daerah rawan dimana perusahaan tersebut tidak dapat ditentukan apakah termasuk perusahaan yang bangkrut atau tidak (Hanafi, 2014: 657).

3. Z-Score $<1,81$ dikategorikan sebagai perusahaan yang memiliki kesulitan keuangan yang sangat besar dan berisiko bangkrut (Hanafi, 2014: 657).

\section{Analisis Rasio Altman Z-Score}

Altman pada penelitiannya memfokuskan pada 5 kategori yang mewakili 4 rasio keuangan yaitu rasio likuiditas, profitabilitas, leverage/solvabilitas, dan kinerja. Kategorikategori tersebut yaitu:

1. Modal Kerja terhadap Total Aktiva (Working Capital to Total Assets)

$$
\mathrm{X}_{1}=\frac{\text { Aktiva Lancar }- \text { Hutang Lancar }}{\text { Total Aktiva }}
$$

Mengunakan indikator penelitian yang pernah dilakukan Gilrita, Moch. Dzulkirom dan M.G Wi Endang N.P pada tahun 2015, variabel ini digunakan untuk mengukur kemampuan perusahaan dalam memenuhi kewajiban jangka pendeknya dan untuk mengukur tingkat likuiditas aktiva perusahaan. Sebuah modal kerja yang bernilai positif menunjukkan kemampuan perusahaan untuk 
membayar tagihannya sedangkan apabila sebuah perusahaan memiliki modal yang bernilai negatif maka perusahaan tersebut akan mengalami kesulitan dalam memenuhi kewajibannya.

2. Laba Ditahan terhadap Total Aktiva (Reained Eraning to Total Assets)

$$
\mathrm{X}_{2}=\frac{\text { Laba Ditahan }}{\text { Total Aktiva }}
$$

Sumber : (Hanafi, 2014: 656)

Menggunakan indikator penelitian yang pernah dilakukan Gilrita, Moch. Dzulkirom dan M.G Wi Endang N.P pada tahun 2015, variabel ini merupakan pengukuran profitabilitas kumulatif atau laba ditahan perusahaan yang mencerminkan usia perusahaan serta kekuatan pendapatan perusahaan. Laba ditahan yang rendah mungkin menunjukkan tahun bisnis yang buruk atau pengurangan umur bagi perusahaan

3. Laba Sebelum Bunga dan Pajak terhadap Total Aktiva (Earning before Interest and Taxes to Total Assets)

$$
\mathrm{X}_{3}=\frac{\text { Laba Sebelum Bunga dan Pajak }}{\text { Total AKtiva }}
$$

Menggunakan indikator penelitian yang pernah dilakukan Gilrita, Moch. Dzulkirom dan M.G Wi Endang N.P pada tahun 2015, variabel yang termasuk dalam rasio profitabilitas ini memiliki fungsi untuk mengukur kemampuan perusahaan dalam menghasilkan laba dari aktiva yang digunakan atau dapat dikatakan sebagai ukuran produktivitas aset perusahaan.

4. Nilai Pasar Saham Biasa dan Preferen terhadap Nilai Buku Total Hutang (Market Value of Equity to Book Value of Total Liabilities)

$$
\begin{aligned}
& \mathrm{X}_{4}=\frac{\text { Nilai Pasar Saham biasa dan Preferen }}{\text { Nilai Buku Total Hutang }} \\
& \text { Sumber : (Hanafi, 2014: 656) }
\end{aligned}
$$

Menggunakan indikator penelitian yang pernah dilakukan Gilrita, Moch. Dzulkirom dan M.G Wi Endang N.P pada tahun 2015, variabel $\mathrm{X}_{4} \mathrm{X}_{4}$ digunakan untuk menggambarkan solvabilitas (leverage) yang berupa kemampuan finansial jangka panjang suatu perusahaan dan untuk mengetahui besarnya modal perusahaan yang digunakan untuk menanggung beban hutang.

5. Penjualan terhadap Total Aktiva (Sales to Total Assets)

$$
\begin{gathered}
\mathrm{X}_{5}=\frac{\text { Penjualan }}{\text { Total Aktiva }} \\
\text { Sumber : (Hanafi, 2014: 656) }
\end{gathered}
$$

Menggunakan indikator penelitian yang pernah dilakukan Gilrita, Moch. Dzulkirom dan M.G Wi Endang N.P pada tahun 2015, variabel ini berfungsi untuk mengukur kemampuan manajemen dalam menggunakan aktiva untuk menghasilkan penjualan dan menggambarkan tingkat perputaran seluruh aktiva perusahaan.

\section{KAJIAN METODE ALTMAN Z-SCORE}

Sopiyah Arini dan Triyonowati (2013) dalam penelitiannya analisis altman Z-Score untuk memprediksi kebangkrutan perusahaan farmasi di Indonesia. Jenis penelitian yang digunakan adalah penelitian deskriptif. Hasil penelitian ini menunjukkan bahwa model Altman Z-Score dapat diimplementasikan dalam mendeteksi kemungkinan terjadi kebangkrutan pada perusahaan farmasi yang terdaftar di Bursa Efek Indonesia.

Mar'ati Nafisatin, Suhadak, dan Rustam Hidayat (2014) dalam penelitian implementasi penggunaan metode Altman Z-Score untuk menganalisis estimasi kebangkrutan studi pada PT Bursa Efek Indonesia Periode 2011- 
2013. Jenis penelitian yang digunakan adalah penelitian deksriptif kuantitatif. Hasil penelitian menunjukkan bahwa pada perusahaan listing 8 perusahaan berada dalam kondisi aman selama tiga tahun berturutturut, sedangkan 1 perusahaan lainnya berada dalam kondisi rawan. Perusahaan delisting menunjukkan bahwa 7 perusahaan berada dalam kondisi berpotensi bangkrut selama tiga tahun berturut-turut,sedangkan 2 perusahaan lainnya berada dalam kondisi yang berfluktuatif.

Nadia Iswari Putri dan Lucia Ari Diyani (2016) dalam penelitian analisis rasio keuangan dan altman Z-Score untuk menilai kinerja keuangan serta memprediksi kebangkrutan pada PT. Herba Medica Indonesia tahun 20102012. Metode analisis deksriptif kuantitatif dan kualitatif. Hasil analisis yang dilakukan menunjukkan bahwa kinerja keuangan PT. Herba Medica Indonesia pada tahun 2010 sampai dengan 2012 cukup baik. Perusahaan mengalami peningkatan setiap tahunnya dan nilai z-score $>2,90$ yang menunjukkan bahwa perusahaan berada di kategori tidak bangkrut.

\section{METODE PENELITIAN}

\section{Jenis Penelitian}

Penelitian ini menggunakan jenis penelitian deskriptif dengan pendekatan kuantitatif. Menurut (Arikunto, 2007: 234) Penelitian deskriptif merupakan penelitian yang dimaksudkan untuk mengumpulkan informasi mengenai suatu gejala yang ada, yaitu keadaan gejala menurut apa adanya saat penelitian dilakukan. Metode penelitian deskriptif dengan pendekatan secara kuantitatif ini dilakukan dengan cara menganalisis datadata laporan keuangan perusahaan kemudian ditabulasikan agar dapat menentukan kategori perusahaan tersebut dapat dikatakan sehat atau tidak. Penelitian ini mendiskripsikan dan menjelaskan peristiwa atau suatu kejadian yang terjadi pada saat sekarang dalam bentuk angka-angka yang bermakna dengan dukungan studi kepustakaan sehingga lebih memperkuat analisa peneliti dalam membuat suatu kesimpulan yang berdasarkan kriteria atau standar yang telah ditentukan. Dimana hasil penelitian diperoleh dari hasil perhitungan indikator-indikator variabel penelitian kemudian dipaparkan secara tertulis oleh penulis. Penelitian ini menggunakan jenis data sekunder yaitu berupa laporanlaporan keuangan perusahaan yang akan diteliti. Data secara tidak langsung diperoleh peneliti dari internet melalui situs resmi Bursa Efek Indonesia (www.idx.co.id).

\section{Teknik Pengumpulan Data}

Teknik pengumpulan data dengan penelitian pustaka dan dokumentasi. Penelitian pustaka berupa jurnal-jurnal dan buku-buku manajemen keuangan serta teori analisis kinerja perusahaan dan teori analisis kebangkrutan. Dokumentasi berupa data profil perusahaan dan laporan keuangan perusahaan farmasi.

\section{Populasi dan Sampel}

Populasi dalam penelitian ini adalah 10 perusahaan manufaktur sektor industri barang konsumsi sub sektor farmasi. Teknik pengambilan sampel pada penelitian ini adalah teknik purposive sampling dan memperoleh sampel yaitu 5 perusahaan industri farmasi yang secara rutin menyajikan data lengkap dan mempublikasikan laporan keuangan secara berturut-turut dari tahun $2011-2015$.

\section{HASIL DAN PEMBAHASAN}

Perhitungan nilai Altman Z-score

1. Hasil Perhitungan dan Analisis Metode Altman Z-Score pada tahun 2011 
Tabel 1. Hasil Perhitungan dan Analisis Metode Altman Z-Score pada tahun 2011

\begin{tabular}{clcccccc}
\hline No & Nama Perusahaan & $\mathbf{1 , 2}_{1}$ & $\mathbf{1 , 4}_{2}$ & $\mathbf{3 , 3 X}_{3}$ & $\mathbf{0 , 6} \mathbf{X}_{4}$ & $\mathbf{1 , 0} \mathbf{X}_{5}$ & Z-Score \\
\hline 1 & $\begin{array}{l}\text { PT Kimia Farma } \\
\text { (Persero) Tbk }\end{array}$ & 0,54 & 0,14 & 0,46 & 1,39 & 1,94 & 4,47 \\
2 & $\begin{array}{l}\text { PT Kalbe Farma } \\
\text { Tbk }\end{array}$ & 0,64 & 1,08 & 0,79 & 2,23 & 1,32 & 6,06 \\
3 & $\begin{array}{l}\text { PT Tempo Scan } \\
\text { Pasific Tbk }\end{array}$ & 0,60 & 0,84 & 0,59 & 1,52 & 1,36 & 4,91 \\
4 & $\begin{array}{l}\text { PT Darya-Varia } \\
5\end{array}$ & 0,72 & 0,55 & 0,63 & 2,18 & 1,05 & 5,13 \\
& Laboratoria Tbk & 0,88 & 1,09 & 1,62 & 3,29 & 1,57 & 8,45 \\
\hline
\end{tabular}

Berdasarkan tabel 1. hasil perhitungan di atas menunjukkan bahwa kelima perusahaan sektor farmasi tahun 2011 berada pada kondisi keuangan yang baik artinya tidak mengalami kebangkrutan $(Z>2,99)$. PT Merck Tbk memiliki nilai Z-Score tertinggi dampak dari tingginya nilai variabel $\mathrm{X}_{1}$, variabel $\mathrm{X}_{2}$, variabel $\mathrm{X}_{3}$ dan variabel $\mathrm{X}_{4}$ dibandingkan dengan perusahaan lainnya. Jika dilihat dari satu persatu variabel, pada variabel $\mathrm{X}_{5}$ (Modal Kerja / Total Aktiva) bernilai tinggi dampak dari tingginya aktiva lancar diatas hutang lancar terhadap total aktiva. Besarnya aktiva lancar meliputi besarnya kas dan setara kas, piutang usaha pada pihak ketiga, serta piutang lain-lain. Pada hutang lancar memiliki nilai yang besar dampak dari besarnya utang usaha pihak relasi, utang pajak penghasilan dan utang pajak lainnya. Besarnya total aktiva dampak dari aktiva lancar ditambah aktiva tidak lancar. Aktiva tidak lancar meliputi besarnya aset tak berwujud untuk pembelian perangkat lunak komputer dan besarnya aset keuangan lainnya.

Variabel $\mathrm{X}_{2}$ (Laba Ditahan / Total Aktiva) bernilai tinggi akibat dari laba perusahaan yang diperoleh dari penjualan properti investasi
Perseroan sebanding dengan peningkatan total aktiva mengakibatkan laba yang ditahan perusahaan besar jumlahnya.

Variabel $\mathrm{X}_{3}$ (Laba Sebelum Bunga dan Pajak / Total Aktiva) bernilai tinggi akibat dari tingginya beban bunga perusahaan dan laba yang diperoleh perusahaan seperti penjualan properti sebanding dengan besarnya total aktiva.

Variabel $\mathrm{X}_{4}$ (Nilai Pasar Saham Biasa dan Preferen / Nilai Buku Total Hutang) bernilai tinggi dampak dari kenaikan sebagai akibat dari kenaikan laba komprehensif perseroan yaitu peningkatan laba usaha sebanding dengan besarnya jumlah hutang yang terdiri dari hutang lancar dan tidak lancar. Hutang tidak lancar memiliki nilai yang besar dampak peningkatan utang usaha pihak relasi, utang pajak penghasilan dan utang pajak lainnya.

Variabel kelima $\mathrm{X}_{5}$ (Penjualan / Total Aktiva) menunjukkan penjualan atau pendapatan PT Merck Tbk sudah baik jika dilihat dari peningkatan penjualan dari divisi farmasi dan kimia PT Merck Tbk. Namun rasio PT Merck Tbk lebih kecil dibandingkan PT Kimia Farma (Persero) Tbk.

\section{Hasil Perhitungan dan Analisis Metode Altman Z-Score pada tahun 2012}

Tabel 2. Hasil Perhitungan dan Analisis Metode Altman Z-Score pada tahun 2012

\begin{tabular}{llcccccc}
\hline No & Nama Perusahaan & $1,2 \mathrm{X}_{1}$ & $1,4 \mathrm{X}_{2}$ & $3,3 \mathrm{X}_{3}$ & $0,6 \mathrm{X}_{4}$ & $1,0 \mathrm{X}_{5}$ & Z-Score \\
\hline 1 & $\begin{array}{l}\text { PT Kimia Farma } \\
\text { (Persero) Tbk }\end{array}$ & 0,56 & 0,14 & 0,46 & 1,36 & 1,80 & 4,32 \\
2 & $\begin{array}{l}\text { PT Kalbe Farma } \\
\text { Tbk }\end{array}$ & 0,58 & 1,06 & 0,83 & 2,16 & 1,45 & 6,08 \\
3 & $\begin{array}{l}\text { PT Tempo Scan } \\
4\end{array}$ & 0,60 & 0,85 & 0,59 & 1,57 & 1,43 & 5,04 \\
4 & $\begin{array}{l}\text { Pasific Tbk } \\
\text { PT Darya-Varia }\end{array}$ & 0,71 & 0,62 & 0,66 & 2,17 & 1,01 & 5,17 \\
5 & $\begin{array}{l}\text { Laboratoria Tbk } \\
\text { PT Merck Tbk }\end{array}$ & 0,72 & 0,92 & 0,86 & 1,64 & 1,63 & 5,77 \\
\hline \multicolumn{7}{c}{ Sumber : Data diolah }
\end{tabular}


Berdasarkan tabel 2. hasil perhitungan di atas menunjukkan bahwa kelima perusahaan sektor farmasi tahun 2012 berada pada kondisi keuangan yang baik artinya tidak mengalami kebangkrutan $(Z>2,99)$. PT Kalbe Farma Tbk memiliki nilai Z-Score tertinggi dampak dari tingginya nilai pada variabel $\mathrm{X}_{2}$ jika dibandingkan dengan perusahaan yang lainnya. Jika dilihat dari satu persatu variabel, pada variabel $\mathrm{X}_{1}$ (Modal Kerja / Total Aktiva) PT Kalbe Farma Tbk memiliki nilai rasio lebih kecil dibandingkan dengan PT Darya-Varia Laboratoria Tbk dan PT Merck Tbk. Akan tetapi, PT Kalbe Farma Tbk menunjukkan nilai yang sudah baik jika dilihat dari peningkatan aktiva lancar diatas hutang lancar terhadap total aktiva. Aktiva lancar memiliki nilai yang besar dampak dari besarnya piutang usaha, piutang lain-lain atas klaim pembelian potongan penjualan dan piutang karyawan, aset keuangan lainnya terutama didorong reksadana, obligasi serta dana yang dibatasi penggunaannya terkait dengan fasilitas Letter of Credit ( $L C$ ) pada salah satu entitas anak, persediaan peningkatan kebutuhan bahan baku, persediaan barang dalam proses dan barang jadi, pajak pertambahan nilai dibayar di muka, aset lancar lainnya terutama disebabkan pembayaran uang muka untuk pembelian aset tetap terkait tanah dan mesin produksi. Hutang lancar memiliki nilai yang besar dampak dari besarnya utang bank di mana pinjaman jangka pendek dalam mata uang Rupiah diperoleh dari PT Bank CIMB Niaga Tbk, fasilitas cerukan (overdraft) dari PT Bank Central Asia Tbk dan PT Bank Permata Tbk kredit berjangka dalam mata uang asing diperoleh dari The Hong Kong and Shanghai Banking Corporation Ltd cabang Jakarta dan PT Bank Central Asia Tbk dalam Dolar A.S, serta pinjaman tetap dalam mata uang Dolar
Singapura dari DBS Bank. Besarnya utang usaha dari pembelian bahan baku dan barang jadi dari prinsipal pihak ketiga di bidang usaha distribusi. Besarnya utang lain-lain dampak dari utang kepada agen periklanan dan perusahaan ekspedisi. Naiknya beban akrual untuk biaya promosi serta peningkatan taksiran utang pajak penghasilan utang sewa pembiayaan. Total aktiva yang meningkat akibat jumlah aktiva lancar dan aktiva tidak lancar, aktiva tidak lancar didorong oleh peningkatan aset tetap, aset pajak tangguhan serta aset tidak berwujud.

Variabel $\mathrm{X}_{2}$ (Laba Ditahan / Total Aktiva) bernilai tinggi akibat dari besarnya laba usaha yang diperoleh perusahaan sebanding dengan peningkatan total aktiva.

Variabel $\mathrm{X}_{3}$ (Laba Sebelum Bunga dan Pajak / Total Aktiva) sudah memiliki nilai yang baik jika dilihat dari peningkatan beban pajak penghasilan serta pertumbuhan penjualan dan laba bruto yang sehat, namun nilai rasio yang dimiliki PT Kalbe Farma Tbk ini lebih kecil dibandingkan dengan PT Merck Tbk.

Variabel $\mathrm{X}_{4}$ (Nilai Pasar Saham Biasa dan Preferen / Nilai Buku Total Hutang) menunjukkannilaiyangbaikyaknipeningkatan yang terutama disumbangkan oleh akumulasi saldo laba sehubungan dengan program pembelian kembali saham serta jumlah saham yang dibeli kembali oleh Perseroan, namun rasio yang dimiliki PT Kalbe Farma Tbk ini masih lebih kecil dibandingkan PT DaryaVaria Laboratoria Tbk.

Variabel kelima $\mathrm{X}_{5}$ (Penjualan /Total Aktiva) menunjukkan peningkatan penjualan dari divisi distribusi dan logistik kepada prinsipal pihak ketiga sudah memiliki nilai yang baik, Namun rasio PT Kalbe Farma Tbk ini masih lebih kecil dibandingkan perusahaan farmasi lainnya. 


\section{Hasil Perhitungan dan Analisis Metode Altman Z-Score tahun 2013}

Tabel 3. Hasil Perhitungan dan Analisis Metode Altman Z-Score pada tahun 2013

\begin{tabular}{cllllllll}
\hline No & Nama Perusahaan & $\mathbf{1 , 2} \mathbf{X}_{1}$ & $\mathbf{1 , 4}_{2}$ & $\mathbf{3 , 3} \mathbf{X}_{\mathbf{3}}$ & $\mathbf{0 , 6}_{\mathbf{4}}$ & $\mathbf{1 , 0 \mathbf { X } _ { 5 }}$ & $\mathbf{Z}$-Score \\
\hline 1 & $\begin{array}{l}\text { PT Kimia Farma } \\
\text { (Persero) Tbk }\end{array}$ & 0,50 & 0,13 & 0,40 & 0,90 & 1,73 & 3,66 \\
2 & $\begin{array}{l}\text { PT Kalbe Farma } \\
\text { Tbk }\end{array}$ & 0,52 & 0,94 & 0,76 & 1,8 & 1,41 & 5,43 \\
3 & $\begin{array}{l}\text { PT Tempo Scan } \\
\text { Pasific Tbk }\end{array}$ & 0,59 & 0,80 & 0,53 & 1,46 & 1,27 & 4,65 \\
4 & $\begin{array}{l}\text { PT Darya-Varia } \\
\text { Laboratoria Tbk }\end{array}$ & 0,70 & 0,63 & 0,53 & 1,82 & 0,92 & 4,60 \\
5 & $\begin{array}{l}\text { PT Merck Tbk } \\
0,76\end{array}$ & 0,95 & 1,22 & 1,66 & 1,71 & 6,3 \\
\hline \multicolumn{7}{c}{ Sumber : Data diolah }
\end{tabular}

Berdasarkan tabel 3. hasil perhitungan di atas menunjukkan bahwa kelima perusahaan sektor farmasi tahun 2013 berada pada kondisi keuangan yang baik artinya diperdiksikan tidak mengalami kebangkrutan $(Z>2,99)$. PT Merck Tbk memiliki nilai Z-Score tertinggi dampak dari tingginya nilai variabel $\mathrm{X}_{+}$, variabel $\mathrm{X}_{3}$ dan variabel $\mathrm{X}_{2}$ dibandingkan dengan perusahaan lainnya. Jika dilihat dari satu persatu variabel, pada variabel $\mathrm{X}_{1}$ (Modal Kerja / Total Aktiva) bernilai tinggi dampak dari tingginya aktiva lancar diatas hutang lancar terhadap total aktiva. Besarnya aktiva lancar disebabkan besarnya kenaikan dalam jumlah kas dan setara kas, piutang usaha pada pihak ketiga, persediaan dan biaya dibayar dimuka. Besarnya hutang lancar disebabkan oleh kenaikan utang usaha pada pihak ketiga, utang pajak penghasilan dan liabilitas jangka pendek lainnya. Besar jumlah total aset akibat aset lancar ditambah aset tidak lancar. Aset tidak lancar terutama karena adanya kenaikan pada uang muka untuk pembelian aset tetap dan kenaikan pada aset pajak tangguhan.

Variabel $\mathrm{X}_{2}$ (Laba Ditahan / Total Aktiva) bernilai tinggi akibat dari besarnya jumlah laba ditahan untuk investasi masa depan dalam proyek-proyek riset, pengembangan bisnis dan belanja modal sebanding dengan peningkatan jumlah total aktiva.
Variabel $\mathrm{X}_{3}$ (Laba Sebelum Bunga dan Pajak / Total Aktiva) bernilai tinggi akibat dari tingginya laba yang diperoleh perusahaan dan meningkatnya beban bunga perusahaan sebanding dengan besarnya aktiva yang dimiliki perusahaan.

Variabel $\mathrm{X}_{4}$ (Nilai Pasar Saham Biasa dan Preferen / Nilai Buku Total Hutang) sudah dianggap memiliki nilai yang baik jika dilihat dari kenaikan sebagai akibat dari kenaikan laba komprehensif Perseroan yaitu peningkatan laba usaha setelah dikurangi dengan pembayaran dividen di tahun 2013 yang sebanding dengan besarnya jumlah hutang yang terdiri dari hutang lancar dan tidak lancar. Hutang tidak lancar meliputi peningkatan disebabkan oleh meningkatnya provisi untuk imbalan kerja, namun rasio yang dimiliki PT Merck Tbk lebih kecil dari PT Darya-Varia Laboratoria Tbk.

Variabel kelima $\mathrm{X}_{5}$ (Penjualan / Total Aktiva) menunjukkan penjualan atau pendapatan PT Merck Tbk sudah baik jika dilihat dari kenaikan penjualan dari divisi obat resep merck serono PT Merck Tbk, namun rasio yang dimiliki masih lebih kecil dibandingkan PT Kimia Farma (Persero) Tbk. 


\section{Hasil Perhitungan dan Analisis Metode Altman Z-Score tahun 2014}

Tabel 4

Hasil Perhitungan dan Analisis Metode Altman Z-Score pada tahun 2014

\begin{tabular}{llcccccc}
\hline No & Nama Perusahaan & $\mathbf{1 , 2} \mathbf{X}_{\mathbf{1}}$ & $\mathbf{1 , 4 \mathbf { X } _ { 2 }}$ & $\mathbf{3 , 3} \mathbf{X}_{\mathbf{3}}$ & $\mathbf{0 , 6} \mathbf{X}_{\mathbf{4}}$ & $\mathbf{1 , 0 \mathbf { X } _ { 5 }}$ & $\mathbf{Z}$-Score \\
\hline 1 & PT Kimia Farma & 0,47 & 0,11 & 0,40 & 0,80 & 1,50 & 3,28 \\
& $\begin{array}{l}\text { (Persero) Tbk } \\
2\end{array}$ & & & & & & \\
3 & PT Kalbe Farma Tbk & 0,55 & 0,99 & 0,76 & 2,19 & 1,40 & 5,89 \\
& $\begin{array}{l}\text { PT Tempo Scan } \\
\text { Pasific Tbk }\end{array}$ & 0,53 & 0,83 & 0,46 & 1,60 & 1,34 & 4,76 \\
4 & PT Darya-Varia & 0,71 & 0,66 & 0,33 & 1,93 & 0,89 & 4,52 \\
& Laboratoria Tbk & & & & & & \\
5 & PT Merck Tbk & 0,78 & 0,99 & 0,99 & 1,96 & 1,21 & 5,93 \\
\hline \multicolumn{7}{l}{ Sumber : Data diolah }
\end{tabular}

Berdasarkan tabel 4. hasil perhitungan di atas menunjukkan bahwa kelima perusahaan sektor farmasi tahun 2014 berada pada kondisi keuangan yang baik artinya tidak mengalami kebangkrutan $(Z>2,99)$. PT Merck Tbk memiliki nilai Z-Score tertinggi dampak dari tingginya nilai variabel $\mathrm{X}_{1}$, variabel $\mathrm{X}_{2}$ dan variabel $\mathrm{X}_{3}$ dibandingkan dengan perusahaan lainnya. Jika dilihat dari satu persatu variabel, pada variabel $\mathrm{X}_{1}$ (Modal Kerja / Total Aktiva) bernilai tinggi dampak dari tingginya aktiva lancar diatas hutang lancar terhadap total aktiva. Besarnya aktiva lancar disebabkan besarnya kenaikan dalam jumlah kas dan setara kas, piutang usaha pada pihak relasi, persediaan dan aset lancar lainnya. Besarnya hutang lancar disebabkan oleh kenaikan utang usaha pada pihak relasi, utang pajak penghasilan dan liabilitas jangka pendek lainnya. Besar jumlah total aset akibat aset lancar ditambah aset tidak lancar. Aset tidak lancar terutama karena adanya kenaikan pada pengembalian pajak, dan aset tidak berwujud serta aset tidak lancar lainnya.

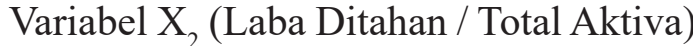
bernilai tinggi akibat dari besarnya jumlah laba ditahan untuk investasi masa depan dalam proyek-proyek riset, pengembangan bisnis dan belanja modal sebanding peningkatan jumlah total aktiva.
Variabel $\mathrm{X}_{3}$ (Laba Sebelum Bunga dan Pajak / Total Aktiva) bernilai tinggi akibat dari tingginya laba yang diperoleh perusahaan serta meningkatnya beban bunga perusahaan sebanding dengan besarnya aktiva yang dimiliki perusahaan.

Variabel $\mathrm{X}_{4}$ (Nilai Pasar Saham Biasa dan Preferen / Nilai Buku Total Hutang) sudah dianggap memiliki nilai yang baik jika dilihat dari kenaikan laba komprehensif perseroan yaitu kenaikan pendapatan keuangan dan penurunan pajak tangguhan di tahun 2014 setelah dikurangi dengan pembayaran dividen di tahun 2014 sebanding dengan besarnya jumlah hutang yang terdiri dari hutang lancar dan tidak lancar. Besarnya hutang tidak lancar dampak dari peningkatan provisi untuk imbalan kerja, namun rasio yang dimiliki PT Merck Tbk masih lebih kecil dari PT Kalbe Farma Tbk.

Variabel kelima $\mathrm{X}_{5}$ (Penjualan / Total Aktiva) menunjukkan penjualan atau pendapatan PT Merck Tbk sudah baik, namun memiliki rasio lebih kecil dibandingkan PT Kimia Farma (Persero) Tbk yang merupakan dampak dari divisi kimia PT Merck Tbk dihentikan operasinya. 


\section{Hasil Perhitungan dan Analisis Metode Altman Z-Score tahun 2015}

Tabel 5. Hasil Perhitungan dan Analisis Metode Altman Z-Score pada tahun 2015

\begin{tabular}{llclllll}
\hline No Nama Perusahaan & $\mathbf{1 , 2}_{1}$ & $\mathbf{1 , 4}_{2}$ & $\mathbf{3 , 3}_{\mathbf{3}}$ & $\mathbf{0 , 6 \mathbf { X } _ { \mathbf { 4 } }}$ & $\mathbf{1 , 0 \mathbf { X } _ { 5 }}$ & $\mathbf{Z}$-Score \\
\hline 1 & $\begin{array}{l}\text { PT Kimia Farma } \\
\text { (Persero) Tbk }\end{array}$ & 0,37 & 0,11 & 0,40 & 0,82 & 1,50 & 3,20 \\
2 & $\begin{array}{l}\text { PT Kalbe Farma } \\
3\end{array}$ & 0,56 & 1,01 & 0,66 & 2,38 & 1,31 & 5,92 \\
4 & $\begin{array}{l}\text { Tbk } \\
\text { PT Tempo Scan }\end{array}$ & 0,50 & 0,80 & 0,40 & 1,34 & 1,30 & 4,34 \\
5 & $\begin{array}{l}\text { Pasific Tbk } \\
\text { PT Darya-Varia }\end{array}$ & 0,65 & 0,60 & 0,40 & 1,45 & 0,95 & 4,05 \\
& $\begin{array}{l}\text { Laboratoria Tbk } \\
\text { PT Merck Tbk }\end{array}$ & 0,66 & 0,95 & 1,02 & 1,69 & 1,53 & 5,85 \\
\hline \multicolumn{5}{c}{ Sumber : Data diolah } & &
\end{tabular}

Berdasarkan tabel 5. hasil perhitungan di atas menunjukkan bahwa kelima perusahaan sektor farmasi tahun 2015 berada pada kondisi keuangan yang baik artinya tidak mengalami kebangkrutan $(Z>2,99)$. PT Kalbe Farma Tbk memiliki nilai Z-Score tertinggi dampak dari tingginya nilai variabel $\mathrm{X}_{2}$ serta variabel $\mathrm{X}_{4}$ dibandingkan dengan perusahaan lainnya. Jika dilihat dari satu persatu variabel, pada variabel $\mathrm{X}_{1}$ (Modal Kerja / Total Aktiva) PT Kalbe Farma Tbk memiliki nilai rasio lebih kecil dibandingkan dengan PT Darya-Varia Laboratoria Tbk dan PT Merck Tbk. Akan tetapi, PT Kalbe Farma Tbk menunjukkan nilai yang sudah baik jika dilihat dari peningkatan aktiva lancar diatas hutang lancar terhadap total aktiva. Besarnya aktiva lancar dampak dari besarnya kas dan setara kas, piutang usaha, pajak pertambahan nilai dibayar di muka. Pada besarnya nilai hutang lancar dampak dari besarnya utang bank jangka pendek dalam mata uang rupiah diperoleh dari PT Bank CIMB Niaga Tbk, dari Citibank N.A. dalam mata uang Dolar A.S dan dari DBS Bank Ltd dalam mata uang Dolar Singapura. Fasilitas cerukan (overdraft) dalam mata uang rupiah diperoleh dari PT Bank Central Asia Tbk, PT Bank Danamon dan Citibank N.A, besarnya beban akrual untuk biaya penjualan, utang pajak akibat peningkatan pajak penghasilan. Besar jumlah total aktiva akibat aktiva lancar ditambah aktiva tidak lancar. Besarnya aktiva tidak lancar mengalami peningkatan investasi pada entitas asosiasi, aset tetap, aset pajak tangguhan, tagihan restitusi pajak penghasilan dan aset tidak lancar lainnya.
Variabel $\mathrm{X}_{2}$ (Laba Ditahan / Total Aktiva) bernilai tinggi akibat dari besarnya laba perusahaan yang ditahan untuk kebutuhan dan rencana perluasan usaha Perseroan sebanding dengan peningkatan total aktiva.

Variabel $X_{3}$ (Laba Sebelum Bunga dan Pajak / Total Aktiva) bernilai baik dilihat dari besarnya laba yang diperoleh perusahaan dan beban bunga perusahaan sebanding dengan besarnya total aktiva. Namun nilai rasio yang dimiliki PT Kalbe Farma Tbk lebih kecil dari PT Tempo Scan Pasific Tbk dan PT Merck Tbk.

Variabel $\mathrm{X}_{4}$ (Nilai Pasar Saham Biasa dan Preferen / Nilai Buku Total Hutang) bernilai tinggi dampak dari peningkatan yang disumbangkan oleh akumulasi saldo laba dan kepentingan non-pengendali sebanding dengan besarnya jumlah hutang yang terdiri dari hutang lancar dan tidak lancar. Besarnya hutang tidak lancar dampak dari peningkatan utang bank jangka panjang yang terutama merupakan pinjaman investasi dalam mata uang rupiah kepada PT Bank Central Asia Tbk yang diberikan kepada entitas anak, PT Kalbe Milko Indonesia, besarnya liabilitas imbalan kerja jangka panjang yakni peningkatan liabilitas imbalan kerja karyawan.

Variabel kelima $\mathrm{X}_{5}$ (Penjualan / Total Aktiva) menunjukkan nilai penjualan PT Kalbe Farma Tbk sudah baik sebanding dengan peningkatan total aktiva, Namun memiliki rasio lebih kecil dibandingkan PT Kimia Farma (Persero) Tbk yang bila ditelusuri perusahaan ini mengalami perlambatan pertumbuhan penjualan karena dampak melemahnya daya 
beli masyarakat, penarikan salah satu obat resep dan berakhirnya kontrak distribusi dengan salah satu prinsipal pihak ketiga yang tidak dilanjutkan sejak akhir tahun 2014.

\section{PENUTUP}

\section{Kesimpulan}

Berdasarkan hasil analisis dari pembahasan yang telah diuraikan pada bab sebelumnya, maka dapat diambil kesimpulan sebagai berikut :

1. Hasil dari analisis kebangkrutan mengunakan metode Altman (Z-Score) pada tahun 2011 sampai dengan 2015 kelima perusahaan farmasi yaitu PT Kimia Farma (Persero) Tbk, PT Kalbe Farma Tbk, PT Tempo Scan Pasific Tbk, PT Darya-Varia Laboratoria Tbk dan PT Merck Tbk berada dalam kategori sehat atau tidak bangkrut, karena ditinjau dari nilai Z-Score seluruh perusahaan menunjukkan hasil melebihi standart Z-Score yaitu 2,99 serta tidak ada nilai rasio yang bernilai negatif, hal ini menunjukkan kinerja keuangan perusahaan tersebut baik.

2. Dari kelima perusahaan farmasi yang dianalisis diperoleh hasil bahwa PT Merck Tbk pada tahun 2011, 2013 dan tahun 2014 memiliki nilai Z-Score paling tinggi yaitu sebesar 8,45, 6,3 dan 5,93.

3. PT Kalbe Farma Tbk pada tahun 2012 dan tahun 2015 memiliki nilai Z-Score paling tinggi yaitu sebesar 6,08 dan 5,92.

\section{Saran}

1. Diharapkan kepada perusahaan untuk menjaga likuiditasnya dalam memenuhi semua kewajibannya sehingga menarik minat para investor dan kreditor.

2. Diharapkan kepada perusahaan untuk mempertahankan dan mengoptimalisasi stabilitas modal kerja melalui pengelolaan klaim pembelian potongan penjualan dan persediaan.

3. Diharapkan perusahaan dapat mengelola aktiva secara efektif dan efisien untuk meningkatkan penjualan dan menghasilkan laba yang besar.

Disarankan pada peneliti selanjutnya, menganalisis terhadap kondisi kebangkrutan suatu perusahaan tidak menggunakan satu jenis model analisis serta penelitian selanjutnya tentang prediksi kebangkrutan menggunakan metode Altman Z-Score tidak dilakukan secara deskriptif saja namun bisa dilakukan pengembangan untuk diuji pengaruh harga saham.

\section{DAFTAR PUSTAKA}

Arief, Pratiwi, Octarie. 2015. Analisis Penerapan Metode Altman Z-score Dan Zmijewski Pada Perusahaan Manufaktur Sektor Industri Barang Konsumsi Sub Sektor Farmasi Periode 2009 - 2013. Skripsi. Jurusan Manajemen Fakultas Ekonomi dan Bisnis Universitas Hasanuddin Medan. Diakses tanggal 29 Oktober 2016.

Arini, S. dan Triyonowati. 2013. Analisis Altman Z-Score Untuk Memprediksi Kebangkrutan Pada Perusahaan Farmasi di Indonesia. Jurnal Ilmu dan Riset Manajemen Vol. 2 No. 11. Sekolah Tinggi Ilmu Ekonomi Indonesia (STIESIA) Surabaya. Diakses tanggal 28 Oktober 2016.

Arikunto, Suharsimi. 2007. Manajemen Penelitian. Cetakan ke-9. Jakarta : PT Rineka Cipta.

Endarwati, Oktiani. 2016. Industri Farmasi Targetkan Tumbuh 11\%. Koran sindo. com. Diakses tanggal 29 Oktober 2016

Hanafi, Mamduh M. 2014. Manajemen Keuangan. Cetakan ke-7. Yogyakarta : BPFE.

Kasmir. 2015. Analisis Laporan Keuangan. Jakarta : PT Raja Grafindo Persada.

Kemenperin. 2016. Industri Farmasi Indonesia Tumbuh Rp 37 T. Bisnis.vivanews.com. 
Diakses tanggal 29 Oktober 2016.

Kurniawanti, Butet Agrina. 2012. Analisis Penggunaan Altman Z-Score Untuk Memprediksi Potensi Kebangkrutan Perusahaan Makanan dan Minuman yang Terdaftar di BEI 2007-2011. Jurnal Skripsi. Fakultas Ekonomi Universitas Gunadarma. Diakses tanggal 27 Oktober 2016.

Nafisatin, Mar'ati,. dkk. 2014. Implementasi Penggunaan Metode Altman (Z-Score) Untuk Menganalisis Estimasi Kebangkrutan(Studi pada PT Bursa Efek Indonesia Periode 2011-2013). Jurnal Administrasi Bisnis (JAB)|Vol. 10 No. 1. Diakses tanggal 01 November 2016.

Putri, Nadia Iswari. dan Diyani, Lucia Ari. 2016. Analisis Rasio Keuangan dan Metode Z-Score untuk Menilai Kinerja Keuangan serta Memprediksi Kebangkrutan pada PT. Herba Medica Indonesia Tahun 2010 - 2012. Kalbisocio Volume 3 No. 1. Diakses tanggal 01 November 2016.

Rafles,. dkk. 2015. Analisis Prediksi Kebangkrutan Perusahaan Dengan Menggunakan Metode Altman (Z-Score)(Studi pada Subsektor Rokok yang Listing dan Perusahaan Delisting di Bursa Efek Indonesia Tahun 2009 - 2013). Jurnal Administrasi Bisnis (JAB) | Vol. 2 No. 1. Diakses tanggal 28 Oktober 2016.

Http://www.idx.co.id Diakses 29 Oktober 2016. 